\title{
Historical Learning Challenges to University Students in Malaysia
}

\author{
Uqbah Iqbal* \\ Researcher, History Programme, Faculty of Social Sciences and Humanities, Malaysia
}

Submission: November 03, 2017; Published: November 20, 2017

*Corresponding author: Uqbah Iqbal, Researcher, History Programme, Faculty of Social Sciences and Humanities, UKM 43650 Bangi Selangor, Malaysia, Email: uqbah@siswa.ukm.edu.my

\section{Mini Review}

Learning is defined as an effort to influence one's emotions, intellectual, and spiritual in order to learn by his own will (Nata, 2009: 85). Through the learning process will create a learning experience that can enhance the morale and activeness of learners. Learning is a systematic process or activity that is interactive and communicative between educators and students in the classroom and beyond the classroom (Arifin, 2009: 11). In the sense of learning there are two actions that are learning done by educators and educators conducted. Leo Agung \& Sri Wahyuni (2013: 5) stated that the purpose of learning is in fact the change in student behavior in both the cognitive, affective and psychomotor fields.

This article was written because the author wanted to cast his views on the historical learning scenario at the university today. It is based on the author's experience while doing his $\mathrm{PhD}$ in the university. Firstly, the process of collecting historical resources requires researcher to the National Archives of Malaysia. However the author sees the location of this archive unsuitable because it is located in a remote area of Kuala Lumpur's popular public transport such as Monorail, KTM and LRT. The author himself will use a taxi or Grab Car service to the National Archives if he does not use his own vehicles. The position of the National Archives, which is seen separately from the bustle of the city, has made it impossible for many to visit it, making it a quiet place most of the time when the author visits it for material collection. Because the majority of the National Archives users are students that have limited financial resources, the author's hopes for this place are accessible to them, as well as the community if we want to rebuild the field of history in Malaysia for the future.

Secondly, the author sees that learning of existing history program is more appreciative of past events that have taken place. It requires strong memory memorization to university students. Unfortunately, after graduation, if unlucky, the author sees that the majority of the history program students will have trouble getting jobs because the program does not specialize in any of the areas of indispensable skill in the current job world. If they do not succeed in getting jobs in the government sector, they will not succeed in finding a place in the private sector that is more oriented to work experience and related skills.

The author sees that in order to overcome this problem, it is appropriate that history students not only master the knowledge of history, but they can also be planted with knowledge from other related programs such as international relations, political science, literature as well as program from other major such as business studies. History students should be exposed to current developments around them and not just focus on past things alone. Our focus is not only to produce historical students who can graduate, but how they will contribute to the nation's development after graduation.

In this challenging new era, we can find that other people who are not in the field of history can even talk about historical events if they are strongly reading and knowledgeable. What's more, if the individual age has grown older and has gone through many important events in the country. This situation does not benefit historical students because history involves facts that anyone can talk about if they are using the correct method. Hence, the author sees the importance of students from history program exposed to other fields of knowledge besides history to improve their self-quality during their studies.

Third, the author hopes that history students can master English as well as Bahasa Malaysia which is the main language. This is important because through English, we will easily find a wider source of information because most international reference books are in English. Through English proficiency as well, history students will not have trouble referring Englishspeaking archive files. English proficiency is also important to help students gain employment in the private sector. If they 
choose to open their own business, they still need to speak English when choosing to venture overseas markets and when communicating with other races within the country.

Fourth, the author sees that the working situation of collecting historical resources in libraries and archives can provide long-term side effects to history students, whether emotional problems such as depression, stress, are not social. The method of historical learning must balanced with social activity so that history students will remain cheerful and eager to pursue knowledge. When students are cheerful, their brain will easily process new information and think critically. There is anxiety in the author when he sees the atmosphere of gathering historical information that can have side effects on the researcher.
Fifth, history students starting from degree studies should be exposed to the outside world through their involvement. The author suggests that the degree students should also have the opportunity to publish their articles in any international journal. This can train themselves to become a quality young historian. They can also participate in any organized writing competition within the country. It can provide added value to them as well as classroom learning activities only. The author hopes to see a huge surge in the world history of Malaysia so that people do not see graduates of history as second class and have no place in the world of work. There is a big transformation that needs to be started from now if we want to see student recruitment for history program remaining relevant for the present and future.

\section{Your next submission with Juniper Publishers} will reach you the below assets

- Quality Editorial service

- Swift Peer Review

- Reprints availability

- E-prints Service

- Manuscript Podcast for convenient understanding

- Global attainment for your research

- Manuscript accessibility in different formats

( Pdf, E-pub, Full Text, Audio)

- Unceasing customer service

Track the below URL for one-step submission https://juniperpublishers.com/online-submission.php 